\title{
The Concept of Education for Santri NU Collaborate with Ideas and Muhamadiyah in Spreading Peace
}

\author{
Annisa Nur Indriyanti ${ }^{1}$ \\ ${ }^{1}$ State Islamic University of Syarif Hidayatullah, Jakarta. \\ 1annisa@uinjkt.ac.id
}

\begin{abstract}
Education is a vital factor in influencing personality. On the issue of radicalism, education is the main factor that causes a person can be exposed to radicalism. Radicalism in the world of education is usually caused by very poor understanding of religion. So easy to understand the radical cause. This understanding is usually the most developed among the students. Additionally, a figure which is expected to become an actor Peace keeping namely students. However, for now the concept of students was adopted by the group. Through the issue, Indonesia needs a figure who can balance out the problems of this radicalism. The aim of this study was sparked concept initiated learning for students as actors of peace among young people. Akann research results obtained are: the similarity of the learning concept boarding NU and Muhammadiyah, Muhammadiyah and NU accepted the idea of Islamic moderation, the concept of students whose learning is integrated with the idea of NU and Muhammadiyah. Empirically method used is qualitative method. This method uses a historical approach that is focused on the data mengkomparas past and present. The data used are primary and secondary.
\end{abstract}

Keywords: Students, Education, NU and Muhammadiyah, Peace

\section{INTRODUCTION}

Indonesia in a pluralistic country with various kinds of differences. Differences in Indonesia can be seen in terms of religious ethnicity, culture and religion. Currently being the fuss is religious differences and a lack of tolerance towards co-religionists. All people want to look and perform best, compared to other religions, no matter how what would be disclosed, either smooth or rough method is being used. Coarse way claimed by the public that it is an act of radicalism[1]. Their actions in Indonesia radiklisme really bersebrangan with the ideology that advocates for maintaining unity among the people of Indonesia, both in terms of ethnicity, religion and culture. Cases of radicalism trending discussed is the problem of radicalism that occurs in Islam. The 
spread of these problems usually begin to spread in the world of education, especially in terms of religious learning.

Based on data yang diunkapkan by the Defense Minister Mr. Ryamizard Ryacudu to say there was about 23.4 percent of the students who have been exposed to radicalism and khilafah agree if their establishment in Indonesia[2]. The data, seriously threatening the ideology of Pancasila to be agreed with the people of Indonesia. It is unfortunate masala is growing rapidly among students, where student was Agent Of Change (actor changes). Hope become a actor who can bring Indonesia grama good progress, but the existence of this problem, a sense of nationalism they are mixed with stains slander actors who want to destroy the state of Indonesia. According to data revealed by BNPT (National Agency Penanulanan Terrorism) Brijen Pol Hamli stated that there are two factors that cause the spread of radicalism highest level among students is a factor less religious understanding and lack of understanding of nationhood[3]. Through these two factors, easy to infiltrate and growing radicalism among students.

Islam as a religion that wants to make Muslims have a character personality and critical reasoning. Religious teachings also suggest not understand religion through a source that is not valid, resulting in misconceptions in the understanding of the Qur'anic text. Then according M.Solahudin their religious misunderstandings occur, for their understanding of the Qur'an textually alone, without the contextual understanding, understanding of sociological and anthropological factors include the verse [4]. As for the problem of the lack of understanding of religion mediate requires someone who can mediate the same age and religious understanding less and can cause radical action. According to the Minister of Religious Affairs Lukman Hakim, Indonesia needs to ground the students role in mediating the issue of radicalism among young people [5]. However, the new Islama ORMAS group developed the concept of religious education through students, newly initiated by NU and Muhammadiyah also recently started to develop the concept of the stretcher lately. At least from kesantrian initiated the concept of each - each group has a different concept. From every aspect of the difference warrants further evaluation to make an ideal students in Indonesia in bringing peace.

Those problems, focusing to dig deeper into the issues that are warm radicalism in Indonesia, especially in the field of education. To mediate understanding of religion is very less among students, Indonesia needs a figure very own background as a complex religious education students. However, the problem is that there are no students who really - really claim to Indonesia in terms of the whole. Then, this research will provide a formulation of the problem, how the concept of the ideal students, who direpsentasikan of two large organizations in Indonesia?. The purpose of this research is looking for the students who had been expected to bring peace in Indonesia, as well as representing the idea of the concept of two organizations which have admitted keeksistensian students.

\section{RESEARCH AND METHODS}


The method used in this research is qualitative method. Definition qualitative methods are methods that are more often used to assess the social sciences that depend on human observation alone [6]. One specification of this method, usually rarely to be found with the numbers - numbers. This method uses an approach that seeks analyst descriptive analysis of the data obtained and then poured into an idea. Sources used are primary and secondary sources.

Specifications of this research is to use historical research methods approach. Historical is a method that focuses in the past addressed the issue in terms of sociology, psychology and anthropology of the incident [7]. Through the data that suggests about the past, then will comporated with a new understanding gained today. The aim its use to facilitate receiving new information from a study. The shape of the research is to find how much data to talk about schools, students in the past and the present. then look for the value - the value that is suitable for students being an ideal concept in Indonesia at this time, which can bring peacefull. The perpose is that the millennial peace actor has Qibla example.

\section{RESULT AND DISCUSSION}

Radicalism in Indonesia is sometimes used as an issue to be dealt with or even some that utilize existence of this problem for the benefit of one group of persons sau. Therefore, the need for a review in advance about the definition of radicalism. Raikalisme is a notion adopted a group that wants change or social reform and politic drastically by using violence [1]. The danger of radicalism is measured from actions caused by such an understanding. The action changes are application- of this vision, could lead to war unity Indonesian society or could be murder.

Strong expression as the number of religious harmony in the presentation Indonesian society can be seen from the data from the Ministry of Religion. Religion Ministry issued the index data concerning religious harmony in Indonesia in 2019. The conclusion from these data, the percentage number of religious harmony today is, 78.83 percent of which addressed the good news compared to last data of 70.90 [8]. However, the good news, no proportionate straight with the case - the case of intolerance was rampant in Indonesia. In fact, sometimes until no new cases of intolerance that occurred in Indonesia.

In addressing the problem of radicalism, education is a vital aspect to be given a strong foundation. Referring Act - No. 14 of 2015 on teachers and lecturers, that every teacher should get legal protection, profession, as well as labor and health protection, teachers or lecturers at this time, still not up to attention in accordance with the law - the law. So many educators are beyond the control of their personality in the education space. And create educational goals are not realized according to expectations, that humanize a humane manner.

Ideals - ideals Indonesian government to make the people of Indonesia are moderate, the talk which was quite warm. Every show that aired on television stations have also appealed to the notion that society is quite horrendous Indonesia. Definition of moderation of Islam itself is a view 
or attitude that is always trying to take a middle position of the two attitudes on both sides [9]. Two attitudes on both sides includes too biased attitude to the West or to the East, more simpelnya the two attitudes is a matter between the radical or liberal attitude.

Their idea of Islamic moderation had invited the pros and cons of the organization Islamic organizations. Yet, strangely between two large organizations in Islam, does not deny the existence of this idea and accept it very well. Both of these organizations to be labeled as a guard moderatisme Islam in Indonesia [10]. Because of Muhammadiyah and NU were not fighting the hallmark our islamic by violent means. Approval of the second argument of this organization makes the importance of grounding the modernization of Islam among other organizations.

To support their notion of Islamic moderation in Indonesia need for strengthening scholars archipelago. Cleric archipelago that would support this notion is, M.Quraish Shihab, he is an archipelago in modern-day commentators who strongly support the existence of religious moderation. According to religious moderation is a concept that should be implemented Muslims. Islamic moderation that inovated by M.Quraish Shihab also a bit of character moderation in Islam, He describes the nature of moderate Islamic moderation is not owned by Muslims were not inclined toward excess - overage or underestimate the various issues related to religion or the world [11]. The idea is to try to have no excessive space in response to religion.

Moderation religion is considered to have the potential to maintain the harmony of the coreligionists. The concept of the value of religious moderation consists of four key elements, honesty, openness, compassion and flexibility [12]. The fourth concept, full support in bringing peace is being expected. Objectives proposed by this very noble religious moderation. Because in this concept fully supports the value - the value in maintaining the integrity and unity, especially among the people of Indonesia who came from different religions.

The existence of the number of students in Indonesia have been very significant in the plurality there exsistant radicalism problem. Pupils in Indonesia is believed to have potential against various problems emerging radicalism in Indonesia. It can be seen from the everyday concept of students in communicating with Kyai [13]. Honourable nature santri against a teacher to be one factor in understanding stem radicalism. Since it is usually something that is taught to students of Kyai is not a political or other interests. Thus, with the concept of communication has been unbelievable, if students have the potential to bring peace in Indonesian society.

Pesantren as a container that spawned generations can better combines all peace. Scientific were always motivated by the religious understanding of the complex, making it easily exposed to radicalism. The concept of learning offered at the school, there were three, by example, through a learning process, through environmental design schools that reflect the culture of tolerance, mutual respect, and have a certain ta'dzim karimah [14]. Behavior that would be owned by the students will be performing berkarkter than children - children who are educated through the public schools. 
Indonesia as an Islamic state world has a lot of organizations - organizations, one of which is NU (Nahdlatul Ulama). NU is the organization of the Islamic period were very large in Indonesia based on the number of followers. NU is an Islamic organization that is consistent with the Indonesian state ideology. It can be seen from nationalistic motives owned NU and has a goal to bring together scholars with leaders - religious leaders in the fight against colonialism in Indonesia [15]. NU-owned national motifs, support the creation of value - the value of peace in it.

In education, $\mathrm{NU}$ has the concept of a traditional education that compatible Indonesia culture with religion. The educational concept Yag poured in a container commonly known as pesantren. Pupils NU has a different characteristic to the boarding school students who carried the Islamic period other organizations. A significant characteristic lies in the concept of a traditionalist [16]. Pupils NU more than happy to discuss with using the concept talking with direct Kyai.

Organization of the Islamic period in Indonesia's second largest is the Muhammadiyah. Muhammadiyah there exsistant recognized as the number of followers in Indonesia is very dominant. The followers of this organization has to differences with previous organizations, it can be seen starting from the founder KHAhmad Dahlan coming from Jogja. These organizations characterize his Islam through the concept of modern education [17]. In stark contrast to the concept of education offered by NU, which tend to be traditional.

During this time, many people thought that the students an education concept offered by NU. However, it does not apply. Muhammadiyah is starting merabah into the concept of multicultural education that is contained in the concept of students at the school. Only the personal significance of the different students themselves. Pupils belonging to more modern Muhammadiyah. Modernization initiated in terms of concept learning, Muhammadiyah tries to make students more savvy with technology. So that graduating from the school not only get science - the science of reading books and other religions. However, students can also appear as a child - school children outside as junior and senior.

Evidence pesatren initiated by Muhammadiyah is not inferior to schools initiated by NU. Muhammadiyah schools established total there are 325 schools that is widespread throughout Indonesia [18]. Significance schools founded by Muhammadiyah can be viewed in terms of its founders and the character models pembelajatannya. Through these data, Muhammadiyah and NU appeared together in characterizing Islam through education.

In the context of peace, $\mathrm{Nu}$ and Muhammadiyah have the same concept of religious understanding, namely, supporting the values of Islamic moderation. It can be seen from the common understanding that follows the flow ahlu Sunnah Wal Jamaah. The most significance difference of the two visits of schools embraced differences, embrace Nu Shafi'i sect, while Muhammadiyah not has school of thought concerning Muslim law [10]. Same understanding flow $\mathrm{NU}$ and Muhammadiyah has excellent potential for voicing moderation of Islam among Muslims in Indonesia. 
To deal with the problem of radicalism in the field of education, it is appropriate when looking for a way out through the concept of education offered NU and Muhammadiyah namely the concept of multicultural education in schools. Currently, schools are not adopted as an educational institution which was initiated by NU, Muhammadiyah but this time also began to move into the realm of education schools. Both of these organizations, to actualize the value - the value of his Islam through a moderate education is not rude manner.

From the similarity of the two organizations that support the idea of religious moderation. This study wants to focus to bring the figure of students who have value - the value of personality derived from the concept of education proposed by NU and Muhammadiyah. The concept offered by the two organizations is the concept of traditional and modern [19]. Through these two concepts will be presented a concept of learning in schools that integrate concepts learned at the school of NU and Muhammadiyah. The goal is to be able to trigger the generation of students who can bring peace in Indonesia. Here the concept of learning that can support schools to bring students to unearth peace:

First, applying sense subject to the Kyai. Tadzim taste for respect indispensable teacher for students, so that students being personally polite and courteous to teachers. Tadzim to teachers is the main concept of learning for students. By following the teacher to make students waffle spared from understanding - understanding of religion come out. Especially the religious understanding of radical and liberal.

Second, learn the yellow book by Mr. Kyai. Yellow book learning is a form of learning Arabic that is very conducive. Through this method, students can directly clarify the understanding gained, if there is a mistake religious understanding gained over the years. The purpose of learning Arabic in general to be able to understand the Qur'an textual and contextual. The purpose of the contextual understanding of the Qur'an is more in terms of sociology and anthropology as well as the rules of the Arabic language contained in the Atar.

Third, read prayers and the litany together. This learning is a form of aplication sunnah exemplified by the Prophet Muhammad. Referring to the hadith about people who practice the Sunnah will get intercession on the Day of Judgment. These learning activities into a clear recommendation to follow a credible source. In addition, this event also as a form of glorifying bagianda Prophet.

Fourth, to master the technology. Usually schools generally do not introduce on learning technology. However, in the middle of the plurality of the very rapid development of the times, boarding school education institutions need to upgrade the skills of the students in the world of technology. It aims to equalize the skills acquired by children - children who are studying in schools or institutions in general. So that students could not be spotted and explored the science of religion, but also be able to explore science as well. The purpose of learning is aligned with the Islamic concept offered to Muslim societies today, namely religious moderation [20] [21]. 


\section{CONCLUSIONS}

Pupils ideal to bring peace is to students who use the concept of learning through this research. The concept pembelajaranya divided into four steps:apply a sense of subject teachers, yellow book learning with Mr. Kiai, read prayers and the litany together, mastering the technology. This concept has the aim to support the government in the ground the idea of religious moderation. As for the expected goals is to counteract the liberal and radical attitude in responding to the understanding of religion.

This research also found the concept of similarity of the two major organizations in Indonesia, Muhammadiyah and NU as adherents understand Ahlu Sunnah Wal Jama'ah. Second, Muhammadiyah and NU have similarities in displaying the Islamic character through education direpsentasikan through pesantren. Owned different aspects of the concept of boarding institutions is of significance, NU tend to show aspects of the traditionalists and Muhammadiyah featuring modern aspects.

\section{REFERENCES}

[1] MT Hussein, "The phenomenon of radicalism in Indonesia," Rausyan Fikr, Vol. 13, no. 2, 2017.

[2] Sri Rahayu and Lisye, "Defense Minister Call 23.4\% Students in RI Exposure Radialisme," 2019. [Online]. Available: https://m.detik.com $/$ news $/$ berita/d4631020/menhan-sebut-234-mahasiswa-di-ri-terpapar-radikalisme. [Accessed: 14-Dec2019].

[3] S. Wildansyah, "BNPT Present Entry of Radicalism Into Causes Campus," 2019. [Online]. Available: https://m.detik.com/news/berita/4091027/bnpt-paparkan-penyebab-masuknyaradikalisme-ke-kampus. [Accessed: 14-Nov-2019].

[4] M. Solahudin, "In the interpretation of the Koran," Al-Bayan J. Stud. Qur'an and Tafseer 1.2, Vol. 2, no. December, pp. 115-130, 2016.

[5] F. Adiwisastra, "Rasta As Ambassador for World Peace," 2019. [Online]. Available: https://m.detik.com/news/kolom/d-4755333/santri-sebagai-duta-perdamaian-dunia.

[6] PS Grace, "Qualitative Research" Journal Equilibrium, Vol. 5 No. 9. pp. 1-8, 2009.

[7] Alian, "History Methodology and Implementation In the study," pp. 1-14, 2005.

[8] JN Satria, "Menag Announce 2019 index of Religious Harmony," 2019. [Online]. Available: $\quad$ https://m.detik.com/news/berita/d-4818287/menag-umumkan-indekskerukunan-beragama-2019. [Accessed: 14-Dec-2019].

[9] M. Mustaqim, "THE POLITICS OF NATIONALITY SANTRI: Up Gait Political Studies Nahdlatul Ulama," addin, Vol. 9, no. 2, pp. 333-348, 2015.

[10] Z. Darajat, "Muhammadiyah and NU: Guard Moderatisme Islam in Indonesia," Hayula Indones. J. Multidiscip. Islam. Stud., Vol. 1, no. 1, pp. 81-96, 2017.

[11] I. Zamimah, "Moderatisme Islam in the Context of Indonesian-ness," J. Al-Fanar, Vol. 1, no. 1, pp. 75-90, 2018.

[12] A.-QUR An and AND implementation, "Concept of Moderation In Values," in 2018. 
[13] M. Hidayat, "Kyai Communication Model With Pupils at School," J. ASPIKOM, Vol. 2, no. 6, p. 385, 2017.

[14] PDEPEM Aqüicultura et al., "No. 主観 的健康感を中心とした在宅高齢者に おける健康 関 連 指標に関する共 分散 構造 分析Title, "بيئة لداسات اسيوط مجلة, vol.

[15] A. Farih, "Nahdlatul Ulama (Nu) and Contribution in Fight And Defend Independence of the Republic of Indonesia (Homeland)," Walisongo J. penelit. Sauce. Religious, Vol. 24, no. 2, p. 251, 2016.

[16] HM Djumransjah, "Boarding School Education and Self-Reliance Students," Journal of Science Education, Vol. 8, no. 2. pp. 139-149, 2001.

[17] N. Abdullah, "KH Ahmad Dahlan (Muhammad Dervish)," J. Sosiol. Religion, Vol. 9, no. 1, p. 22, 2017.

[18] FE Permana, "This Fast Growth Muhammadiyah Islamic School," 2019. [Online]. Available: https://m.republika.co.id/amp/pgy68v384. [Accessed: 14-Nov-2019].

[19] Muttaqin, "Thought and Management Education Nu and Muhammadiyah," EL NURISLAM J. Educators. and Sos. Religious, Vol. 4, no. 1, pp. 1-39, 2017.

[20] A. Fauzi, 'Moderate Islam, for civilization and humanity, " J. Islam Nusant., Vol. 2, no. 2, p. 232, 2018.

[21] K. Saddhono, N. E. Wardani, and C. Ulya, "Sociopragmatic Approach on Discourse Structure of Friday Prayer's Sermon in Java and Madura Island," J. Lang. Lit., vol. 6, no. $1,2015$. 